\title{
Kocuria koreensis sp. nov., isolated from fermented seafood
}

\author{
Eun-Jin Park, ${ }^{1}$ Seong Woon Roh, ${ }^{1,2}$ Min-Soo Kim, ${ }^{1,2}$ Mi-Ja Jung, ${ }^{1}$ \\ Kee-Sun Shin ${ }^{2}$ and Jin-Woo Bae ${ }^{1,2}$ \\ ${ }^{1}$ Department of Life and Nanopharmaceutical Sciences and Department of Biology, Kyung Hee \\ University, Seoul 130-701, Republic of Korea \\ ${ }^{2}$ University of Science \& Technology, Biological Resources Center, KRIBB, Daejeon 305-806, \\ Republic of Korea
}

Correspondence

Jin-Woo Bae

baejw@khu.ac.kr

\begin{abstract}
A Gram-positive, aerobic, non-motile and coccoid actinobacterium, designated $\mathrm{P} 31^{\top}$, was isolated from a traditional, fermented seafood. The strain was catalase-positive and oxidasenegative. Cells grew in the presence of $0-15.0 \%(\mathrm{w} / \mathrm{v}) \mathrm{NaCl}$, and at $\mathrm{pH} 5-10$ and $15-37{ }^{\circ} \mathrm{C}$. Major cellular fatty acids were anteiso- $C_{15: 0}$, anteiso- $C_{17: 0}$ and iso- $C_{16: 0}$. Strain $P 31^{\top}$ contained MK-7 as the predominant menaquinone. The DNA G+C content of the genomic DNA of strain $\mathrm{P} 31^{\top}$ was $65.2 \mathrm{~mol} \%$. A phylogenetic analysis based on the 16S rRNA gene sequence indicated that strain $\mathrm{P} 31^{\top}$ was most closely related to Kocuria kristinae DSM $20032^{\top}$, with $96.9 \%$ similarity, and these two strains clustered together in constructed phylogenetic trees. The DNA-DNA hybridization value between strain $\mathrm{P} 31^{\top}$ and $K$. kristinae DSM $20032^{\top}$ was $21.1 \%$. On the basis of the phenotypic, chemotaxonomic and phylogenetic data, it is suggested that strain P31 ${ }^{\top}$ represents a novel species of the genus Kocuria, for which the name Kocuria koreensis sp. nov. is proposed. The type strain is $\mathrm{P} 31^{\top}\left(=\mathrm{KCTC} 19595^{\top}=\mathrm{JCM} 15915^{\top}\right)$.
\end{abstract}

The genus Kocuria was first proposed by Stackebrandt et al. (1995) on the basis of a detailed phylogenetic and chemotaxonomic analysis of the genus Micrococcus (Stackebrandt et al., 1995). Fifteen species, namely Kocuria aegyptia, K. carniphila, K. erythromyxa, K. flava, $K$. gwangalliensis, $K$. halotolerans, $K$. himachalensis, $K$. kristinae, K. marina, K. palustris, $K$. polaris, K. rhizophila, $K$. rosea, $K$. turfanensis and $K$. varians, currently comprise the genus Kocuria (Stackebrandt et al., 1995; Rainey et al., 1997; Kovacs et al., 1999; Reddy et al., 2003; Kim et al., 2004; Tvrzová et al., 2005; Mayilraj et al., 2006; Li et al., 2006; Zhou et al., 2008; Seo et al., 2009; Tang et al., 2009). The aim of this study was to characterize a strain of the genus Kocuria, which was isolated from a traditional, fermented seafood in Korea.

A novel bacterium, designated $\mathrm{P} 31^{\mathrm{T}}$, was isolated from jeotgal in Korea by using the standard dilution-plating method at $30{ }^{\circ} \mathrm{C}$ on marine agar 2216 (MA; BBL) medium. The isolate was subcultured several times to obtain a pure culture. To determine the optimum culture conditions of strain $\mathrm{P} 31^{\mathrm{T}}$, growth under various conditions was tested.

The GenBank/EMBL/DDBJ accession number for the 16S rRNA gene sequence of strain $\mathrm{P} 31^{\top}$ is $\mathrm{FJ} 607312$.

A supplementary table showing the cellular fatty acid contents of strain $\mathrm{P} 31^{\top}$ and closely related species is available with the online version of this paper.
Temperatures for growth were tested on MA at 4, 10, 15, 20, 25, 30, 37 and $40{ }^{\circ} \mathrm{C}$. The optimum $\mathrm{pH}$ range for growth was determined in marine broth (MB; BBL) adjusted to $\mathrm{pH} 3-10$, at intervals of $1.0 \mathrm{pH}$ unit, with $\mathrm{HCl}$ or $\mathrm{NaOH}$. $\mathrm{NaCl}$ tolerance was tested in $\mathrm{MB}$ prepared without $\mathrm{NaCl}$ to which $\mathrm{NaCl}$ was added to the final concentrations $0.5,1,2,3,5,10,15,20,25$ and $30 \%$, w/v (Gordon et al., 1974; Reichert et al., 1998; Liu et al., 2006). The optimum growth conditions were used for the routine cultivation of strain $\mathrm{P} 31^{\mathrm{T}}$ for physiological and morphological tests. The Gram-staining reaction was performed using a Gram-stain kit (BBL). Motility was determined by the use of semi-solid agar (Tittsler \& Sandholzer, 1936). Morphological characteristics were observed using a light microscope (E600; Nikon) and by transmission electron microscopy. API ZYM and API 20 NE test strips (bioMérieux) and GP2 MicroPlates (Biolog) were used to determine enzyme activities and substrate utilization. Catalase activity was determined by observing bubble production in a $3 \%(\mathrm{v} / \mathrm{v})$ hydrogen peroxide solution and oxidase activity was determined using an oxidase reagent (bioMérieux).

Strain $\mathrm{P} 31^{\mathrm{T}}$ was able to grow at $15-37{ }^{\circ} \mathrm{C}$ (optimum, 30$37{ }^{\circ} \mathrm{C}$ ), at $\mathrm{pH} 5-10$ (optimum, $\mathrm{pH} 5-6$ ) and in the presence of $0-15 \% \mathrm{NaCl}$ (optimum, 0-4\%), but not under anaerobic conditions. Colonies of the strain grown on MA medium were pale cream to pale orange, circular, 
smooth and opaque. Cells were Gram-positive, non-motile and coccoid with a diameter of $1.0-1.5 \mu \mathrm{m}$. The cultural, morphological, physiological and biochemical characteristics of strain $\mathrm{P} 31^{\mathrm{T}}$ and three closely related species of the genus Kocuria are summarized in Table 1.

The extraction and purification of chromosomal DNA were performed as described by Sambrook et al. (1989).

Table 1. Characteristics that differentiate strain $P 31^{\top}$ from closely related type strains of the genus Kocuria

Strains: 1, P31 ${ }^{\mathrm{T}}$ (Kocuria koreensis sp. nov.); 2, K. kristinae DSM $20032^{\mathrm{T}}$; 3, K. rhizophila DSM $11926^{\mathrm{T}} ;$ 4, K. varians DSM $20033^{\mathrm{T}}$. Data for reference type strains were taken from Stackebrandt et al. (1995) and Tvrzová et al. (2005). +, Positive; -, negative; w, weakly positive; NR, no data available.

\begin{tabular}{|c|c|c|c|c|}
\hline Characteristic & 1 & 2 & 3 & 4 \\
\hline \multicolumn{5}{|l|}{ Growth with: } \\
\hline $10 \%(\mathrm{w} / \mathrm{v}) \mathrm{NaCl}$ & + & + & + & - \\
\hline $15 \%(\mathrm{w} / \mathrm{v}) \mathrm{NaCl}$ & + & - & $\mathrm{W}$ & - \\
\hline \multicolumn{5}{|l|}{ Enzyme activity } \\
\hline Oxidase & - & + & - & - \\
\hline Alkaline phosphatase & + & - & + & - \\
\hline L-Arginine dihydrolase & + & + & - & - \\
\hline$\beta$-Galactosidase & - & + & - & + \\
\hline$\beta$-Glucuronidase & - & NR & - & - \\
\hline Urease & + & + & - & + \\
\hline \multicolumn{5}{|l|}{ Hydrolysis of: } \\
\hline Aesculin & - & + & - & - \\
\hline Gelatin & - & - & + & + \\
\hline \multicolumn{5}{|l|}{ Utilization of: } \\
\hline Adenosine & - & NR & - & + \\
\hline L-Arabinose & - & - & + & + \\
\hline Dextrin & - & NR & + & + \\
\hline L-Fucose & - & $\mathrm{NR}$ & + & + \\
\hline Methyl $\alpha$-D-galactoside & - & $\mathrm{NR}$ & - & - \\
\hline D-Galacturonic acid & - & $\mathrm{NR}$ & - & - \\
\hline $\mathrm{N}$-Acetyl-D-glucosamine & - & $\mathrm{NR}$ & + & - \\
\hline 3-Methyl glucose & - & $\mathrm{NR}$ & - & $\mathrm{w}$ \\
\hline D-Glucose-6-phosphate & - & $\mathrm{NR}$ & - & + \\
\hline$N$-Acetyl-L-glutamic acid & - & $\mathrm{NR}$ & - & + \\
\hline Glycerol & + & + & - & - \\
\hline Glycogen & - & $\mathrm{NR}$ & + & + \\
\hline$\beta$-Hydroxybutyric acid & - & NR & - & + \\
\hline myo-Inositol & + & $\mathrm{NR}$ & - & - \\
\hline D-Malic acid & - & NR & + & + \\
\hline Maltose & - & + & - & NR \\
\hline D-Mannitol & + & - & - & - \\
\hline$N$-Acetyl- $\beta$-D-mannosamine & - & $\mathrm{NR}$ & - & - \\
\hline Melibiose & - & - & - & + \\
\hline D-Sorbitol & + & NR & - & + \\
\hline Tween 40 & + & NR & + & + \\
\hline Tween 80 & + & - & + & + \\
\hline Turanose & - & NR & + & + \\
\hline Uridine & - & NR & + & + \\
\hline Xylitol & + & NR & + & + \\
\hline
\end{tabular}

DNA-DNA hybridization was determined using photobiotin-labelled DNA probes as described by Roh et al. (2008). The 16S rRNA gene sequence was amplified by PCR using PCR Pre-Mix (Solgent) and the amplified PCR product was purified using a purification kit (Solgent). Sequencing and phylogenetic analysis were performed as described previously (Roh et al., 2008). The 16S rRNA gene sequences of strain $\mathrm{P} 31^{\mathrm{T}}$ and related taxa were aligned using the multiple-sequence alignment program CLUSTAL $\mathrm{X}$ (Thompson et al., 1997). The MEGA4 program (Tamura et al., 2007) was used to determine phylogenetic relationships between representative strains of the genus Kocuria. The construction of phylogenetic trees was performed using the neighbour-joining (Saitou \& Nei, 1987) and maximum-parsimony (Kluge \& Farris, 1969) methods. Distance matrices were calculated with the method described by Kimura (1980). To investigate the stability of the constructed trees, bootstrap analysis was performed with 1000 replicates.

16S rRNA gene sequence analysis indicated that strain $\mathrm{P} 31^{\mathrm{T}}$ belongs to the genus Kocuria, with highest sequence similarities to sequences from K. kristinae DSM $20032^{\mathrm{T}}$ and $K$. polaris CMS $76 \mathrm{or}^{\mathrm{T}}$ (96.9 and $96.4 \%$, respectively). Strain $\mathrm{P} 31^{\mathrm{T}}$ and K. kristinae DSM $20032^{\mathrm{T}}$ formed a clade in the phylogenetic tree (Fig. 1). The low DNA-DNA relatedness value between strain $\mathrm{P} 31^{\mathrm{T}}$ and $K$. kristinae DSM $20032^{\mathrm{T}}(21.1 \pm 5.97 \%$; mean $\pm \mathrm{SD}, n=3)$ confirmed that strain $\mathrm{P} 31^{\mathrm{T}}$ represents a distinct species.

The genomic $\mathrm{G}+\mathrm{C}$ content was determined by using the thermal denaturation method with SYBR Green and a realtime PCR thermocycler, as described by Gonzalez \& SaizJimenez (2002). The cellular fatty acid compositions of strain $\mathrm{P} 31^{\mathrm{T}}$ and the three most closely related type strains, K. kristinae DSM $20032^{\mathrm{T}}$, K. rhizophila DSM $11926^{\mathrm{T}}$ and $K$. varians DSM $20033^{\mathrm{T}}$, were determined for cultures grown under the same conditions, MA for 2 days at $30{ }^{\circ} \mathrm{C}$. The analysis of the cellular fatty acids was performed by using the standard protocols provided by the MIDI/Hewlett Packard Microbial Identification System (Sasser, 1990) with a 6890 gas chromatograph (Hewlett Packard). Menaquinones were analysed by TLC as described by Hiraishi et al. (1996).

The $\mathrm{G}+\mathrm{C}$ content of the genomic DNA of strain $\mathrm{P} 31^{\mathrm{T}}$ was $65.2 \mathrm{~mol} \%$. This was consistent with values for the other members of the genus Kocuria, which are in the range 6075 mol\% (Stackebrandt et al., 1995; Rainey et al., 1997; Kovacs et al., 1999; Reddy et al., 2003; Kim et al., 2004; Tvrzová et al., 2005; Mayilraj et al., 2006; Li et al., 2006; Zhou et al., 2008). The cellular fatty acid contents of strain $\mathrm{P} 31^{\mathrm{T}}$ and three Kocuria species are shown in Supplementary Table S1 (available in IJSEM Online). Total cellular fatty acids of the genus Kocuria consist of saturated and unsaturated fatty acids (Kim et al., 2004). The predominant cellular fatty acids of strain $\mathrm{P} 31^{\mathrm{T}}$ were anteiso- $\mathrm{C}_{15: 0}(42.9 \%)$, anteiso- $\mathrm{C}_{17: 0}(35.9 \%)$ and iso$\mathrm{C}_{16: 0}(14.9 \%)$. This trend was found in all tested strains 


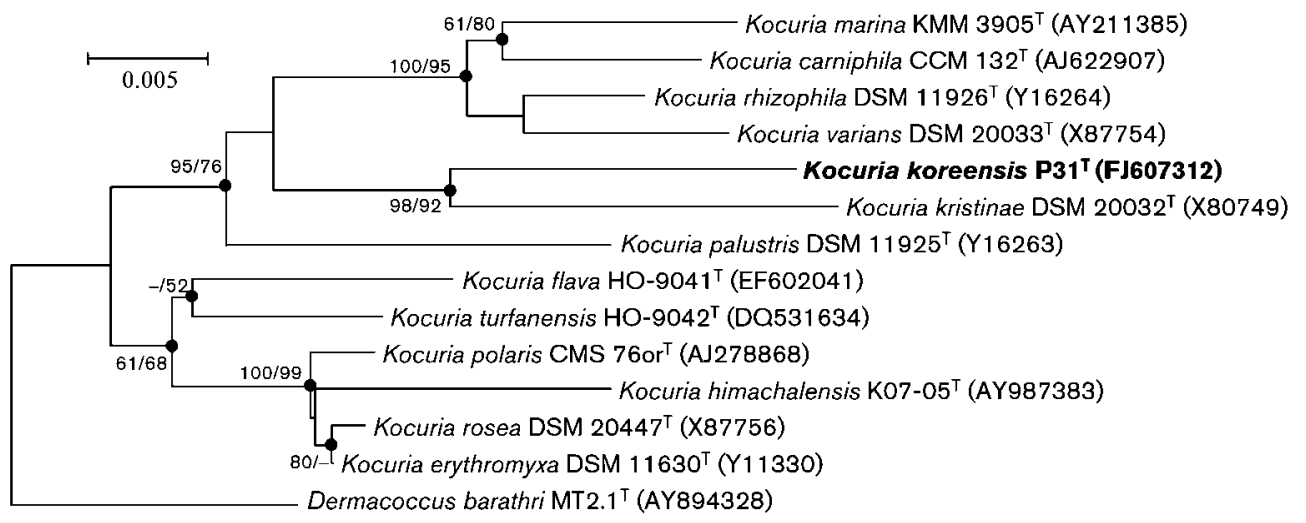

Fig. 1. Neighbour-joining phylogenetic consensus tree showing the relationship between strain $\mathrm{P} 31^{\top}$ and representative strains of the genus Kocuria based on 16S rRNA gene sequences. Filled circles indicate nodes that were also recovered with the maximum-parsimony method. Bootstrap values ( $>50 \%$, neighbour joining/maximum parsimony) based on 1000 resampled datasets are shown at branch nodes. Dermacoccus barathri MT2. $1^{\top}$ was used as the outgroup. Bar, $0.5 \%$ nucleotide substitutions per site.

shown in Supplementary Table S1. Strain $\mathrm{P} 31^{\mathrm{T}}$ contained MK-7 as the predominant menaquinone. MK-7 is also a major menaquinone of $K$. kristinae DSM $20032^{\mathrm{T}}, K$. rhizophila DSM $11926^{\mathrm{T}}$ and K. varians DSM $20033^{\mathrm{T}}$ (Stackebrandt et al., 1995; Tvrzová et al., 2005).

On the basis of the phenotypic, genotypic and phylogenetic data presented, strain $\mathrm{P} 31^{\mathrm{T}}$ represents a novel species of the genus Kocuria, for which the name Kocuria koreensis sp. nov. is proposed.

\section{Description of Kocuria koreensis sp. nov.}

Kocuria koreensis (ko.re.en'sis. N.L. fem. adj. koreensis pertaining to Korea, isolated from Korean fermented seafood, made from comb pen shell).

Cells are Gram-positive, non-motile, aerobic and coccoid with a diameter of 1.0-1.5 $\mu \mathrm{m}$. Optimal growth occurs at $30-37{ }^{\circ} \mathrm{C}$, at $\mathrm{pH} 5-6$ and with $0-4 \% \mathrm{NaCl}$, over $1-2$ days on MA or in MB. Colonies are pale cream or pale orange, circular, smooth and opaque after incubation on MA for 2 days at $30{ }^{\circ} \mathrm{C}$. Catalase-positive and oxidase-negative. Cannot reduce nitrate or produce indole. Cannot hydrolyse aesculin, gelatin or PNPG ( $p$-nitrophenyl $\beta$-D-galactopyranoside). Positive for alkaline phosphatase, L-arginine dihydrolase, esterase (C4), esterase lipase (C8), $\beta$-glucosidase, leucine arylamidase, naphthol-AS-BI-phosphohydrolase and urease. Negative for acid phosphatase, cystine arylamidase, $\alpha$-chymotrypsin, $\alpha$-fucosidase, $\alpha$ - or $\beta$-galactosidases, $\alpha$-glucosidase, $\beta$-glucuronidase, $\alpha$-mannosidase, trypsin and valine arylamidase. According to Biolog GP2 MicroPlates, assimilates Tweens 40 and 80, D-fructose, $\alpha$-Dglucose, myo-inositol, D-mannitol, D-mannose, D-psicose, D-ribose, D-sorbitol, xylitol, acetic acid, $\alpha$-hydroxybutyric acid, $p$-hydroxyphenylacetic acid, L-lactic acid, pyruvic acid methyl ester, pyruvic acid, L-asparagine, glycerol and 2'deoxyadenosine as sole carbon sources. Contains MK-7 as the predominant menaquinone. Major cellular fatty acids are anteiso- $\mathrm{C}_{15: 0}$, anteiso- $\mathrm{C}_{17: 0}$ and iso- $\mathrm{C}_{16: 0}$; minor cellular fatty acids are $\mathrm{C}_{16: 0}$ and iso- $\mathrm{C}_{15: 0}$; trace amounts of iso- $\mathrm{C}_{14: 0}, \mathrm{C}_{14: 0}, \mathrm{C}_{15: 0}$, iso- $\mathrm{C}_{17: 0}$ and $\mathrm{C}_{18: 0}$ are found. The DNA G + C content of the type strain is $65.2 \mathrm{~mol} \%$.

The type strain, $\mathrm{P} 31^{\mathrm{T}}\left(=\right.$ KCTC $\left.19595^{\mathrm{T}}=\mathrm{JCM} 15915^{\mathrm{T}}\right)$, was isolated from a traditional, fermented seafood in Korea.

\section{Acknowledgements}

We thank Dr J. P. Euzéby (École Nationale Vétérinaire, France) for etymological advice. This work was supported by the Environmental Biotechnology National Core Research Center (KOSEF: R15-2003012-02002-0) and TDPAF (Technology Development Program for Agriculture and Forestry) of Ministry for Agriculture, Forestry and Fisheries.

\section{References}

Gonzalez, J. M. \& Saiz-Jimenez, C. (2002). A fluorimetric method for the estimation of $\mathrm{G}+\mathrm{C}$ mol\% content in microorganisms by thermal denaturation temperature. Environ Microbiol 4, 770-773.

Gordon, R. E., Barnett, D. A., Handerhan, J. E. \& Pang, C. H.-N. (1974). Nocardia coeliaca, Nocardia autotrophica, and the nocardin strain. Int J Syst Bacteriol 24, 54-63.

Hiraishi, A., Ueda, Y., Ishihara, J. \& Mori, T. (1996). Comparative lipoquinone analysis of influent sewage and activated sludge by highperformance liquid chromatography and photodiode array detection. J Gen Appl Microbiol 42, 457-469.

Kim, S. B., Nedashkovskaya, O. I., Mikhailov, V. V., Han, S. K., Kim, K.-O., Rhee, M.-S. \& Bae, K. S. (2004). Kocuria marina sp. nov., a novel actinobacterium isolated from marine sediment. Int J Syst Evol Microbiol 54, 1617-1620.

Kimura, M. (1980). A simple method for estimating evolutionary rates of base substitutions through comparative studies of nucleotide sequences. J Mol Evol 16, 111-120. 
Kluge, A. G. \& Farris, J. S. (1969). Quantitative phyletics and the evolution of anurans. Syst Zool 18, 1-32.

Kovacs, G., Burghardt, J., Pradella, S., Schumann, P., Stackebrandt, E. \& Marialigeti, K. (1999). Kocuria palustris sp. nov. and Kocuria rhizophila sp. nov., isolated from the rhizoplane of the narrow-leaved cattail (Typha angustifolia). Int J Syst Bacteriol 49, 167-173.

Li, W.-J., Zhang, Y.-Q., Schumann, P., Chen, H.-H., Hozzein, W. N., Tian, X.-P., Xu, L.-H. \& Jiang, C.-L. (2006). Kocuria aegyptia sp. nov., a novel actinobacterium isolated from a saline, alkaline desert soil in Egypt. Int J Syst Evol Microbiol 56, 733-737.

Liu, Z.-P., Wu, J.-F., Liu, Z.-H. \& Liu, S.-J. (2006). Pseudonocardia ammonioxydans sp. nov., isolated from coastal sediment. Int J Syst Evol Microbiol 56, 555-558.

Mayilraj, S., Kroppenstedt, R. M., Suresh, K. \& Saini, H. S. (2006). Kocuria himachalensis sp. nov., an actinobacterium isolated from the Indian Himalayas. Int J Syst Evol Microbiol 56, 1971-1975.

Rainey, F. A., Nobre, M. F., Schumann, P., Stackebrandt, E. \& Da Costa, M. S. (1997). Phylogenetic diversity of the deinococci as determined by $16 \mathrm{~S}$ ribosomal DNA sequence comparison. Int J Syst Bacteriol 47, 510-514.

Reddy, G. S. N., Prakash, J. S. S., Prabahar, V., Matsumoto, G. I., Stackebrandt, E. \& Shivaji, S. (2003). Kocuria polaris sp. nov., an orange-pigmented psychrophilic bacterium isolated from an Antarctic cyanobacterial mat sample. Int J Syst Evol Microbiol 53, 183-187.

Reichert, K., Lipski, A., Pradella, S., Stackebrandt, E. \& Altendorf, K. (1998). Pseudonocardia asaccharolytica sp. nov. and Pseudonocardia sulfidoxydans sp. nov., two new dimethyl disulfide-degrading actinomycetes and emended description of the genus Pseudonocardia. Int J Syst Bacteriol 48, 441-449.

Roh, S. W., Sung, Y., Nam, Y.-D., Chang, H.-W., Kim, K.-H., Yoon, J.-H., Jeon, C. O., Oh, H.-M. \& Bae, J.-W. (2008). Arthrobacter soli sp. nov., a novel bacterium isolated from wastewater reservoir sediment. J Microbiol 46, 40-44.

Saitou, N. \& Nei, M. (1987). The neighbor-joining method: a new method for reconstructing phylogenetic trees. Mol Biol Evol 4, 406-425.
Sambrook, J., Fritsch, E. F. \& Maniatis, T. (1989). Molecular Cloning: a Laboratory Manual, 2nd edn. Cold Spring Harbor, NY: Cold Spring Harbor Laboratory.

Sasser, M. (1990). Identification of bacteria by gas chromatography of cellular fatty acids, MIDI Technical Note 101. Newark, DE: MIDI Inc.

Seo, Y. B., Kim, D.-E., Kim, G.-D., Kim, H.-W., Nam, S.-W., Kim, Y. T. \& Lee, J. H. (2009). Kocuria gwangalliensis sp. nov., an actinobacterium isolated from seawater. Int J Syst Evol Microbiol 59, 2769-2772.

Stackebrandt, E., Koch, C., Gvozdiak, O. \& Schumann, P. (1995). Taxonomic dissection of the genus Micrococcus: Kocuria gen. nov., Nesterenkonia gen. nov., Kytococcus gen. nov., Dermacoccus gen. nov., and Micrococcus Cohn 1872 gen. emend. Int J Syst Bacteriol 45, 682692.

Tamura, K., Dudley, J., Nei, M. \& Kumar, S. (2007). MEGA4: Molecular Evolutionary Genetics Analysis (MEGA) software version 4.0. Mol Biol Evol 24, 1596-1599.

Tang, S.-K., Wang, Y., Lou, K., Mao, P.-H., Xu, L.-H., Jiang, C.-L., Kim, C.-J. \& Li, W.-J. (2009). Kocuria halotolerans sp. nov., a novel actinobacterium isolated from a saline soil in China. Int J Syst Evol Microbiol 59, 1316-1320.

Thompson, J. D., Gibson, T. J., Plewniak, F., Jeanmougin, F. \& Higgins, D. G. (1997). The CLUSTAL_X windows interface: flexible strategies for multiple sequence alignment aided by quality analysis tools. Nucleic Acids Res 25, 4876-4882.

Tittsler, R. P. \& Sandholzer, L. A. (1936). The use of semi-solid agar for the detection of bacterial motility. J Bacteriol 31, 575-580.

Tvrzová, L., Schumann, P., Sedlácek, I., Pácová, Z., Spröer, C., Verbarg, S. \& Kroppenstedt, R. M. (2005). Reclassification of strain CCM 132, previously classified as Kocuria varians, as Kocuria carniphila sp. nov. Int J Syst Evol Microbiol 55, 139-142.

Zhou, G., Luo, X., Tang, Y., Zhang, L., Yang, Q., Qio, Y. \& Fang, C. (2008). Kocuria flava sp. nov. and Kocuria turfanensis sp. nov., airborne actinobacteria isolated from Xinjiang, China. Int J Syst Evol Microbiol 58, 1304-1307. 